1 | Sulaiman Mappiasse

ISSN 2528-0295 (print)/ISSN 2528-0309 (online)

Journal of Islamic Education Policy

2016, Vol.1, No.1, 1-17

Diterbitkan Online Juni 2016 (http://journal.iain-manado.ac.id/index.php/jiep)

\title{
Similar Trends, Different Agendas: Religious Instruction in Public Schools in Indonesia, Malaysia and Singapore
}

\author{
Sulaiman Mappiasse \\ Fakultas Tarbiyah dan Ilmu Keguruan, Institut Agama Islam Negeri Manado, North Sulawesi, Indonesia \\ Email: sulaiman.mappiasse@iain-manado.ac.id
}

\begin{abstract}
This article argues that national and global events that led to the recent revival of religious education has not altered the nature of the existing arrangement of religious instruction in public schools in Indonesia, Malaysia, and Singapore. Competitive internationalization arena, however, has converged the function of religious education in these countries. It examines how religious instruction in public schools in these ASEAN countries has been transformed in accordance to the emerging demand for global competitiveness. In Indonesia, although the political and economic reform has unsettled the existing structure of the relationship between state and people, the segregated model of religious education classes following religious lines remains in effect. Similarly, in Malaysia, education reform that has been carried out since the early 1990s has not transformed the initial arrangement of religious education. It is still delivered in a way that serves the historical privilege of the Malay ethnic group. Finally, in Singapore, although religious education once gained public popularity, it was only for a short time. The peculiar national agendas of development in each country is argued to be the main determinant of the existing religious education arrangement. Therefore, forces of internationalization arena can only influence the existing state of religious education in a way that serves this national peculiarity.
\end{abstract}

Keywords: religious instruction, religious education, public schools

\section{Introduction}

Since the beginning of the 1980s, there has been a revival in religious education. Many agree that despite the significant effect of the secularization thesis has on the people - that science, technology and modernization will reduce or even abolish the influence of religions on human affairs, religions increasingly play important roles in human affairs (Chaves, 1994; Cush, 2007; Hunges, 2008). There have been many political and social events in different countries that are not possible to be comprehended without taking religion into considerations. September 11, 2001 tragedy, for instance, boggled people's mind of how a religion can urge its adherents to commit destructive actions. A number of crimes and conflicts reported in different countries, another example, often sparked from failure to solve contentious issues in a multireligious and multiracial society. Many nations, therefore, took policy measures to revive religious education in their state school curricula. There has been a wide consensus among policy makers and authorities across countries that religion could not be treated as a personal business anymore. It has become everyone's business (Carmody, 2010, p. 42). It has become a common responsibility of the government and 
their people. However, this similar trend of religious education revival does not necessarily signal an emerging homogeneity of different countries in their national development agendas of religious education. National history, political and social peculiarity of each country can influence how they will carry out a new policy of religious education. The underlying agendas that rationalize the inclusion of the religious education in the state curricula then vary from country to country. This article seeks to examine how national agendas and transnational forces have influenced religious instruction and education in Indonesia, Malaysia and Singapore. The three countries have tried to redefine their religious instruction in the last decades in response to the changing structure of the contemporary politics and society. Against the backdrop of the current internationalization and the intensified media impact of global terrorism, countries in the region are facing similar challenges. It will be, therefore, interesting to compare how the three major members of ASEAN countries redefined their relations to the society through the regulation of religious education in public schools.

As the boundary between public and private schools has been blurred in the late decades (Welch, 2006), there is a need to make it clear from the outset that the use of the phrase 'public school' in this article denotes nonreligious schools that receive public subsidies. As nowadays, both public and private schools receive state funds in many ways, defining what public or private school is based on state fund schemes analytically becomes less useful. By the same token, religious education and instruction is used in this article interchangeable, referring to religious education classes, rather than religious education as an alternative system of education vis-à-vis modern Western education system.

\section{Religious Education in the Contemporary Plural World}

The revival of religious education is not just a regional peculiarity, but it is also a global trend. In Australia, despite the fact that people visit to churches or affiliation to an organized religion has decreased, religious education has become more important for citizens to adapt in the contemporary environment. There has been a trend of religion individualization by which people have spiritual beliefs and practices without referring to resources offered by religious organizations. The emphasis is on the experience of feeling a complete adjustment, security and stability, not of something supernatural. More importantly, the growing presence of immigrant descents in Australian society makes it more difficult to understand social expectations without proper information of various religions (Feinberg, 2006; Hunges, 2008).

In the UK, there has been a bitter debate around the question of religious education: whether it should be included in the state curriculum or not, and how religious education should be so that it becomes educational. There has been a wide consensus that students should be exposed to religious knowledge and values through formal school curriculum. In like manner, concern with religious illiteracy among the youth came out from both secularists and believers in France (Williams, 2008). As many students are lack of religious culture, teaching subjects requiring enough religious literacy like history, philosophy, arts and literacy becomes not easy. A great agreement about the necessity of religious education to be pursued in education system came forth to this end (Estivalezes, 2008).

Furthermore, in the USA, despite the fact that discussions about religious education in public schools are not as vibrant as in the UK, the recent development shows an increasing advocacy for teaching about religions at schools (Grelle, 2008). A number of 
religious groups asserted that religion should become the main ingredient of moral education taught to their children in school (Feinberg, 2006, p. xi). Kollar (2009) vividly describes the situation.

"In a room full of people, very few practice the same religion; they differ in belief, vary in what they say and do on holidays, condemn different sins, and may or may not go to the same house of worship. This is true in our country and needs to be recognized in our public schools" (p.xiii).

Lastly, in Japan, religious education was prevented from public schools for the state constitution strictly regulated the separation between state and religion. However, there has been an increasing demand for constitutional amendment to enable religious education to "conform the culture of the 21 st century" (Filus, 2008, p. 1043).

\section{Rationale of the Religious Instruction}

The state interest to involve in regulating its relations with religion is not without a reason d'être. Religion is believed to have a significant role in helping the state to establish social cohesion needed. State-nation building accordingly is one of the most important reasons behind the inclusion of religious education in school curriculum. As a rule, the nation-state becomes a protector for religious beliefs and practices. Likewise, religions sometimes become resources for resistance. Religious education thus can play an important role in producing a productive tension between the nation-state and religion (Moran, 2008). Religious education can become an effective medium for the state to nurture religious values that will contribute to the national development and progress. Values such as love, peace, tolerance, justice, patience, and perseverance are desirable to any state. Likewise, people can channel their productive criticism to the state using religious values and institutions.

Increasing plurality is another important impetus to the revival of religious education and its inclusion in the state school curriculum. The advance of technology and transportation has alleviated human mobility and interconnectivity. Consequently, people involved in this vibrant and risky environment must have not only knowledgebased skills but also cultural schools. Comprehensive understanding of different religions, beliefs and values in history and society can help citizens to have better tolerance and greater sensitivity to other people of different religions and worldviews. Therefore, people are expected to master these soft skills in order to actively participate in a competitive internationalization arena.

\section{Approaches to Religious Plurality}

In the contemporary multicultural world, the most intriguing question for teachers of the religious education is "Would assertion of cultural and ethnic identity be harmful to unity and solidarity across a population?" (Choi, 2008, p. 147). This is, arguably, an empirical question rather than simply a question that accepts a yes or no answer. Its answer is dependent on one's social experiential response to religious plurality.

Miranda (2010) describes three distinct social responses to the existing plurality: exclusivism, inclusivism, and pluralism. First, exclusivism is a view that one's religion is absolutely true and other's religions are false. Such view is most likely to flourish in a school system that offers religious education in a confessional fashion. Such approach may develop religious chauvinism among its adherents. Religious exclusivism is not problematic in itself. The problem yet occurs when each individual from different religions living in one community holds similar attitudes. Each one accordingly tends to 
excludes one another. Second, inclusivism is a more tolerant response by which religious diversity and plurality is not perceived as a threat to one's belief. Instead, it motivates someone to find out what other religions teach to see if they can learn new things from them. Everyone should speak on their own terms and others should listen assuming that every religion equally can be right or wrong. Lastly, pluralism views that every religion is equally effective in its transforming power. No religion can claim superiority to other religions. Pluralism encourages meaningful encounters among religious and nonreligious people to establish relationships based on mutual understanding, not to develop agreements.

Skei (2008) describes another way of examining how people behave toward plurality, i.e. naturalistic, rationalistic, and romantic. The first attitude perceives that "socio-cultural diversity is inevitable and therefore not something to be lamented" (p.310). The second one views that all human beings are equally equipped with basic capacity to survive. Thus, opportunity to reach a common understanding through critical and rational thinking is always viable. Finally, romantic attitude views that every individual is more or less free and creative. They have ability to think creatively, leading to the appropriation of unique aims; a process that produces plurality in life.

Teaching approach applied in religious education varies from country to country. These approaches could be summerized in three main types, namely (a) a phenomenological approach that teaches religious subjects in a descriptive way by which students can learn about different religions. It is also known as a religious studies approach; (b) a reflective and dialogical approach by which students are taught into religions with the aim of equipping them to make intelligible opinions about religious diversity; and finally (c) a confessional approach by which students are taught into a specific religion with the objective of converting or making them committed to a particular religion (Williams, 2008).

It is argued here that country differences in their approaches to religious education are so much influenced by their national agendas of development (Schreiner, 2002). In Western developed countries, for instance, liberal pluralism and democracy are the main purpose of the societal development. Hence, when it comes to religious education, they will be leaning to an approach that is most likely to effectively nurture religious culture without compromising the virtues of liberal democracy. According to the pluralist view, religious education is not about how to convert someone to a particular belief system. Rather, it is more about "religious nurture and edification" as a way to transmit cultural literacy to the next generation (Grelle, 2008, p. 467).

In some countries, however, when the creation of national harmony is emphasized in their national development, academic considerations in selecting an appropriate approach to the teaching of religious education are usually overlooked (Carmody, 2010, p. 43).

Western liberal pluralism believes that children should be given opportunities to develop critical skills required to reflect and revise their own conceptions, including their religious beliefs and values. Their evaluation should be, of course, based on certain standards of rationality. Unexpectedly, respect nevertheless in many religiously plural societies, according to Feinberg (2006), is expressed in a negative manner, namely simply by avoiding not to talk about religious differences and when a discussion occurs those differences are treated uncritically.

For that reason, educational institutions should play their strategic role to assist nation-states to socialize their young citizens with religious education because these 
institutions can include most population in their formative period of lives. Religious education though is not an easy subject to agree on its organization and content compared to other subjects on account of the fact that each country has its own way of carrying out religious education. This suggests, according to Skeie (2008), that "religious education is one of the most politically sensitive educational issues" (p. 317). Subsequently, religious educators can play an important part in developing and supporting scientifically based knowledge of religious issues in classrooms. Otherwise, they will neglect openness toward different perspectives in religious education that may lead to an "unholy alliance between religion and violence" (Baratte, 2008, p. 244). As a result, the fact that religions share a common support for peace becomes obscure. Many religious educators nevertheless agree that it is inconceivable to apply a purely neutral, objective and descriptive approach in religious education classes. It becomes part of teachers' responsibility then to assist students to separate between description and normativity of religion in religious education (Skeie, 2008).

\section{Comparing Religious Instructions: Indonesia, Malaysia and Singapore}

Religious education for the most part falls in the category of social studies. Many countries share similar goals in including those social subjects in their state curricula. The emphasis is much on developing a common national identity, loyalty and commitment to the state. Such goals place religious education in dilemma because it as a result must navigate and negotiate the competing demands of nationalism, regionalism, and transnationalism. That is to say that parties involved in religious education activities should be in constant negotiations between the interests of a nationstate and the forces of globalization. Adding to this challenge, attachment to a nationstate often becomes irrelevant in the face of contemporary transnational forces (Ho, 2013).

The history of religion and state relationships in different countries shapes how tensions among different interests at different levels is managed (Grelle, 2008). This undoubtedly influences how contents and management of religious education are structured and invented. In the following passages, this article examines the latest development of religious instruction in Indonesia, Malaysia, and Singapore, to find out how an individual country managed its religious education, facing the global wave of religious chauvinism, and competition in internationalization arena.

\subsection{Indonesia}

A heated debate around the location of religious instruction and education in the education system emerged in the early days of the Indonesia's independence. A one year and half discussion led the Indonesian Parliament to take the following policy: "Religious instruction shall be provided in government schools; and parents shall decide whether their children are to attend such instruction" [Education Act No. 4/1950, article 20 (i)] (Kelabora, 1979, p. 325). If students of a nonreligious public school decide to study religions, their marks in the subject will not influence their promotion.

Since strong pressure from Muslim groups and the Ministry of Religious Affairs heightened, the Islamic education system as a whole was excluded from the Education Act 1950, and placed under the Ministry of Religious Affairs. All religious instructions were included in the Act but Islamic religious instruction was placed under the responsibility of the Ministry of Religious Affairs, even if it was to be provided for nonIslamic schools (Kelabora, 1979). From then to the present, the implementation of the 
policy of religious instruction in nonreligious schools has been coordinated jointly by the Ministry of Religious Affairs and the Ministry of Education.

As the significant change in the structure of political power during the time of Guided Democracy after 1960 occurred, this noncompulsory religious instruction was changed to be compulsory for all, from preprimary to university level. The attempted coup of 1965 leading to the victory of the Army and the Muslim groups over the proponent of the communist and the radical nationalist offered a new opportunity to improve the status of religious education in the school curriculum. Religion was considered as a key factor in winning the battle against the atheist communism. The Consultative Assembly in 1966 decided to make religion as a subject in schools from primary to the university level (Kelabora, 1976). This policy remains effective to the present [Education Act No. 2/1989 Article 39 (2), and Education Act No. 20/2003 Article $37(1-2)]$. Religious education is viewed as an effort to strengthen faith and righteousness to the One God in accordance to the religion of each student by observing the obligation to respect other religion followers in tolerant relationships for the sake of national unity. This massage is emphasized again in the recent Government Regulation No. 55/2007 (2) regarding religious education with an additional emphasis on the aim of religious education, namely to develop student ability to understand, reflect, and apply religious values in accordance to their mastery of science, technology, and arts. Furthermore, Pancasila and citizenship education was mandated in the Act 1989 in order to provide moral and civic resources for students. As a fundamental political reform occurred in the late 1990s, Pancasila was presumed to be the object of political abuse during Suharto's regime so that the emphasis on Pancasila education was omitted from the Act 2003.

Following the Big Bang reform in 1997/98, civil conflicts happened in some regions across the country. These conflicts were often portrayed as ethnically based events, such as Dayak-Madura's conflicts in the Central Kalimantan; or religiously based ones such as conflicts between Muslims and Christians in Ambon, and Poso (McRae, 2013; van Klinken, 2007) or within Muslim groups such as conflicts between Sunni and Syi'ah groups in Sampang, Madura, East Java (Tempo, 2012), and conflicts between Ahmadiyya and the traditional established Muslim groups in various places (Burhani, 2014). At the same time, political reform was carried out massively, anchored around the adoption of decentralization policy in governance and multiparty system in politics.

Against this backdrop, there has been an emerging urge to reform Indonesia's education system in curriculum, fund, and management. A drastic change in the orientation of religious education from inward-looking to outward-looking orientation was enthusiastically pursued. Religious education was expected to move away from its indoctrinating and exclusive form. It now should perform a double task, i.e. to assist students to become devotional and nationally committed citizens, and at the same time to remain pluralist, open and tolerant to dialogues and differences. Along with this paradigm shift, religious instruction in contrast must be provided in each school taught by a teacher from the same religion [Education Act No. 20/2003 Article 12 (1)].

In the recent development, people have been concerned with the increasing number of street riots, mostly involving students (Kompas Online, 2013), sex before marriage among school students (Nurjanah, 2015), and the ubiquity of drug users and street gangs among the youth across the nation, from metropolitan cities to remote rural areas. Authorities and people hence started questioning the effectiveness of religious education. What has religious education done for their children? Why could not 
religious education prevent their children from committing anti-social activities? They asked for educational accountability. Religious educators accordingly were blamed for failing to internalize moral values and good conducts to their students according to the divine guidance of religions. People place high expectation on the religious education to play an important role in precluding students from any anti-social activities.

Therefore, in the newly developed state curriculum known as Curriculum 2013, religious education is combined with moral education as one subject called religious and moral education. Likewise, Pancasila education is back and combined with citizenship education. Apparently, instruction is supposedly designed to be active, student-centered, creative, innovative, effective, productive, and fun. Learning process is supposed to be well-designed, closely monitored, and evaluated. Students are expected to meet basic competences that constitute four core competences as follows spiritual, social, knowledge, and skill competence (Khairiyah \& Zen, 2014). Interestingly, these four core competences are applied in an integrative fashion across different subjects, so that religious and moral education is integrated with other subjects, including natural sciences.

The former Ministry of Education and Culture Muh. Nuh in his presentation said,

"Curriculum 2013 emphasizes the importance of strengthening spiritual and social competence of students ... They should turn out to become humanizing people ..."

"All subjects are connected to the core competences of each grade"

(Kemendikbud RI, 2014, p. 43).

Apparently, the government perceives that the development of life and science in the twenty first century emphasizes information, computation, automation, and communication. Such development by all means requires a new kind of capable citizens who have fine mix of good character, knowledge, and skills. Moreover, religious education remains in the center of the state curriculum. Government Regulation No. $55 / 2007$ (1) regarding religious education defines religious education as an education instruction that provides knowledge and shapes attitude, character, and skills of students in observing their own religion teachings. In a government report, religious education is expected to assign a priority to the inculcation of moral values, to deliver a positive and proportional response to the development of science and technology, and to remain as a parameter for all developments related to politics, society, culture and economy (Depdiknas RI, 2007). To put it in another way, religious and moral education has become an encompassing parameter for all school subjects.

\subsection{Malaysia}

Following its independence from the British in 1957, Malaysia became known as the Federation of Malaya. This Federation encompassed Singapore, Sabah, and Sarawak in 1963. The Malaysian population consisted of various ethnics groups, namely Malay (51\%), Other Bumiputera (15\%), Chinese (22\%), Indian (7\%), and Others (0.8\%) (EPU, 2013). Religious affiliation follows these ethnic lines.

One of the major controversial issues at the early stage of Malaysia independence was the question of citizenship among different ethnic groups. While the Malay along with the indigenous people were acknowledged as the most legitimate owners of the land, the right to the citizenship of the Chinese and Indian was questioned. After a bitter debate, an agreement was achieved between different ethnic groups through their political representatives. This agreement is written in the Malaysian constitution Article 153, stipulating that citizenship is granted to the non-Malays wih with the proviso that 
the Malay possess special rights in the field of education, public services, and commerce (Yeoh, 2006). Borrowing Parekh (1991) phrase, Hefner (2001) calls this citizenship division as an "ethnically differentiated citizenship" (p.29).

This historical concession has deep influence on the way education structured in Malaysia. The Education Act 1961 that was released based on the Razak Report (1956), and Rahman Talib Report (1960) suggested the creation of a uniform national education, and centralized examination system, a Malayan-oriented curriculum, one type of national secondary school, compulsory English and Malay language, Malay as the main medium of instruction, and religious and moral education as a basis for spiritual development.

Also, the Act 1961 has a profound effect on the implementation of religious education. Prior to the release of the Act, Islamic religious education was much an informal activity outside school hours. Following its enactment, state-aided schools that are attended at least by 15 Muslim students (now 5, Education Act 1996 Article 50) must provide religious instruction at public expense. Non-Muslim students may receive similar religious instruction as well, but not publicly funded and only if parents' consent is obtained. Such policy should have stimulated the growth of Islamic religious schools. Many Muslim students however opted out to national public schools (Hashim \& Langgulung, 2006; Nor \& Othman, 2011).

Following the ethnic riots on May 13, 1969, the government became vigilant so that any efforts proposed to create national integrity and ethnic harmony will be dealt with full caution. Meanwhile, awareness that Malaysia needs to have a strong national ideology to hold its people in unity emerged. Inspired by Indonesia's Pancasila, Malaysia developed a new national ideology known as Rukun Negara in 1970, consisting of five principles, namely belief in God, loyalty to king and country, upholding the constitution, sovereignty of law, and good behavior and morality. Later, this new Rukun Negara became a source of values for moral education in primary and secondary school curriculum that was adopted in 1983 (Mahmood, 2014). The inclusion of moral education in curriculum was presumably taken as a response to the deterioration of the moral values and indiscipline among the youth. It is worth noting that moral education is compulsory for non-Muslim students, and Muslim students are exempted because they are already taking Islamic religious education. That is to say that moral education was implemented to fulfill the need of non-Muslim students for moral guidance. Both Islamic religious and moral eeducation are examinable subjects (Balakrishnan, 2010; C. L. Hoon, 2010).

Another important development coming out from the ethnic riots of 1969 was a program of affirmative action for the Malay and Indigenous people through the New Economic Policy (NEP). NEP was intended to improve the Bumiputera participation in modern economy, and education was perceived as one of the most vital media to correct the economic backwardness of the Malay. As a result, Malay was made as the only language of tuition, and public examinations were also restricted to the Malay (Brown, 2005). This indicates an increasing control of the Malay people over the state education. To put it differently, ethnic-based riots had led the Malay to reinvent an economic policy that clearly further deepened the Malay domination over the state.

As the demand for places in tertiary education increased due to the limited seats at public universities, higher rate of enrollment, and the expensive cost of overseas education, there has been a change in the politics of education from the early 1980s onwards. Through Education Act 1996 (Act 550), the government opened the gate for 
the private tertiary education sector to flourish, allowing for instruction in languages other than Malay (Brown, 2005).

The Act 1996 is considered as the most comprehensive educational law ever in the history of the country. For the first time, Malaysia wrote its National Educational Philosophy (NEP).

"Education in Malaysia is an on-going effort towards further developing the potential of individuals in holistic and integrated manner so as to produce individuals who are intellectually, spiritually, emotionally and physically balanced and harmonious, based on the firm belief in and devotion to God. Such an effort is designed to produce Malaysian citizens who are knowledgeable and competent, who possess high moral standards, and who are resilient and capable of achieving a high level of personal wellbeing as well as being able to contribute to the betterment of the family, society and the nation at large" (Hashim \& Langgulung, 2006, p. 13)

This education philosophy idealizes balance in life, morality, and wellbeing. More importantly, the Act 1996 emphasizes the culture of excellence based on measured standards. Such policy orientation had a direct impact on the private Islamic religious schools. In the middle of the heightened competitive environment, these Islamic schools were suffering from limited facilities and low quality teachers. As a result, it lost the state subsidy in 2002. Then, the government urged parents to transfer their children to the better national school, and for teachers, to apply for new posts in the national school. This recommendation was howerver undermined by most students and parents (Hashim \& Langgulung, 2006).

\subsection{Singapore}

Like Indonesia and Malaysia, Singapore is a multiethnic and religious country. The population consists of Chinese (76.2\%), Malay (15\%), Indian (7.4\%), and Other (1.4 \%) (Singapore's Department of Statistics, 2014). Religion is distributed along the ethnic lines. Singapore is a secular state that strictly separates state from religion, but supports the right of people to observe their religious beliefs and practices (Kadir, 2010, p. 163; Tan, 2008).

A White Paper on the Maintenance of Religious Harmony Act released on December 26, 1989 states,

"In exercising its right to freely practice one's religion, religious groups in the country should be guided by the following: (a) acknowledge the multiracial and multireligious charter of Singapore society, and the religious sensitivities of other communities; (b) emphasize the moral values common to all faith in the country; (c) respect the right of every individual to freely choose his/her religion; (d) to prevent their followers from acting in any manner which may prove disrespectful towards other religions or religious groups in the country; (e) not influencing or inciting their members to hostility towards other groups, religious and nonreligious" (Louis, 1998, p. 166).

The state survival is a phrase that the government often uses to obtain public support. That is to say that in order for Singapore to thrive in a competitive environment of internationalization, common moral values rather than exclusive religious values are important to be inculcated to students so that their commitment to society and state can be secured. Singapore's emphasis on values of respect, tolerance, patriotism, and respect for law and order (Gopinathan, 1980) generally can be found in almost every 
country offering moral and citizenship education. Singapore, however, has a very strong emphasis on national integration where schools are developed to become the main medium of transmitting values promoting national cohesion among the Singaporean youth.

In 1982, in contrast to the strict stand of the state in separating religion from state, the government with the aim of internalizing local values and traditions in the country included religious instruction in the public school curriculum. There was a belief that different religious values and traditions living in Singapore land can be productive ingredients of moral and civic education. By imparting religious knowledge to students, the young citizens will be able to maintain their national identities in the middle of the pervasive presence of the Western worldview in public sphere.

Prior to the inclusion of religious education in state curriculum, the Ong's Report in moral education suggested that teaching religion is the best way to produce a moral citizen, considering that Singapore did not have a well-developed reference of ideology. This recommendation led the government to approve the inclusion of Bible knowledge and Islamic religious knowledge to be examinable subjects in public school curriculum in 1979. In the later development in 1982, the religious knowledge instruction expanded to include Bible knowledge, Hindu studies, Sikh studies, Islamic religious knowledge, Buddhist studies, and Confucian ethics. In the meantime, an urge to develop a national ideology emerged. In October 28, 1988, the government expressed their concern with the transformation of the Singaporean values from Asian communalism to Western individualism. Accordinlgy, consensus on one Singapore national ideology was pursued and later achieved, namely nation before community and society above self, family as the basic unit of society, regard and community support for the individual, consensus instead of contention, and racial and religious harmony (Louis, 1998).

Againts this backdrop, the expectation to build up a tolerant society through religious education in public schools emerged. There was awarness however that this measure might scale up unhealthy competition in religous activities. The government therefore took some measures at the first place to prevent the teaching from being a breeding ground of religious chauvinism. Indeed, later on it was found that the teaching of religious knowledge at schools was confounded by a strong tendency of segregating ethnic and religious groups. Rather than nurturing national integrity and solidarity among young citizens, it strengthened religious fatalism. Consequently, the subject was withdrawn from being a compulsory subject in 1989 (Lee, 2013), and replaced by civic and moral education (Tan, 2012).

Since its independence to the present, Singapore has reformed its social curriculum no less than ten times in order to adapt to the changing environment. Recently, globalization is one of the most important factors that prompted the state to reinvent its national values agendas. Singapore in internationalization arena seeks to actively participate and contribute to the contemporary global politics and economy, while maintaining its local and national values and identities. In 1997, a report entitled Singapore 21 Report was published, in which a new vision was thoroughly examined and presented. Singapore 21 was described as a vision for a new age. This vision covers five main ideals, namely "every Singaporean matters, strong families: our foundation and our future, opportunities for all, the 'Singapore Heartbeat': feeling passionately about Singapore, and active citizens: making the difference” (Lee, 2013, p. 250).

Recently, in its Curriculum 2015, Singapore has proposed the development of the twenty-first century citizenship competencies, including civic literacy, global awareness 
and cross-cultural skills, critical and inventive thinking, and information and communication skills. These skills and knowledge, according to the Curriculum 2015, must be underpinned by values, such as respect, responsibility, integrity, care, resilience, and harmony. An effective cultivation of these competencies is believed to turn a student into a confident person, self-directed learner, active contributor and concern citizen. The expected future citizens, for Singapore, are ones having concern with the future of the country, committed to the betterment of society as a whole, and ready to make it more competitive at the global stage.

This new vision has restructured the school curriculum to become more integrative. Initially, each subject in school curriculum has its own individual objective standing alone. Interestingly, the agenda of the national development that was steered toward international competitiveness have been able to integrate citizenship education curriculum into general curriculum (Lee, 2013).

\section{Discussions}

In the past, religious education has been adopted in many countries, including several Western developed countries, as part of their agenda of national building and development. Nation-states have an agenda to create a deep commitment to the state through a common ideology or a new brand religion that provides a unified national aspiration and goal (Saeed, 1999).

A general assumption in the modernism literature holds that the economic success of a society will lead to the decline of religious confession and practices (Buckley \& Mantilla, 2013), as demonstrated by Hunges (2008) in the case of Australia. The contemporary revival of religious education in a number of Western developed countries then is a deviation from this assumption. Recently, public authorities and educators in the West show increasing interest to engage in discussions around religious education in school curriculum. This phenomenon cannot be explained by a single factor because many contemporary events have contributed to this revival.

The occurrence of many terrorist actions in last decades committed under the name of religious confession has made many to turn to religious literature in order to find answers of how religions can lead someone to act irresponsibly. The future citizens therefore must receive intelligible answers to address such questions. Otherwise, they will grow carrying misconceptions that will lead to other social tensions that may unsettle national cohesion.

Furthermore, increasing plurality due to the initial influx of immigrant workers to several developed countries has transformed their host countries to become more heterogeneous. Each religious and ethnic group inclines to maintain their own ethnic and religious identities. A high demand for cross cultural education and understanding then occurred to make sure that the state stability will be able to be sustained. Therefore, in most developed countries, religious studies approach in teaching about religion is preferable because, for them, teaching religions should not be a conversion process, rather it should be a process of nurturing religious culture by imparting religious knowledge to the learner. Religious edification is supposed to produce future citizens who have sensitivity to cultures other than their own particular customs and traditions. It is also expected to equip students with a cultural tool to access subjects that require enough religious knowledge (Estivalezes, 2008). 
In the Western developed countries, there has been also an emerging tendency to blame the lack of religious education for the intermittent moral and ethical issues involving youngsters. The underlying assumption of this tendency is that religious education can transmit moral values and conducts to students. Interestingly, in a country, like Australia, there has been a trend to teach students about religions, even to introduce students to their particular religious heritage in a confessional way (Malaysia Today, 2014). As a result, there has been concern that this practice might segregate the future citizens of the country according to the religious and ethnic lines (Zyngier, 2013).

In Indonesia, Malaysia and Singapore, religions are strongly linked to the national agenda of development, state-capacity building, and national integration. The first priority of including religions in the state curriculum therefore is to allow young citizens to develop their national identities through religious knowledge and skills. In Indonesia and Malaysia, religion has been in the center of the nation-building agenda since its independence. Yet, this has not converted both countries to become religious nationstates. Singapore, on the other hand, took a different stand. From its independence, the founders of Singapore enshrined in its constitution that religion must be treated as a personal business, and kept away from the state affairs. This has not nevertheless transformed Singapore to be a nonreligious community. About 85 percent of the population was reported to affiliate themselves with a religion (Tan, 2008). These historical differences to some extent determine the purposes of religious instruction in the state curriculum.

A global wave of democratization and liberalization from the early 1980s and religious terrors in various countries since the late 1990s has prompted Indonesia, Malaysia, and Singapore to reconsider their existing relationship with aspects of religion, including religious education in school.

In Indonesia, since the collapse of Suharto's regime in 1998, there has been a high demand to reorient the focus of religious education from unity to diversity through multicultural based education (Baidhawy, 2007). The teaching arrangement of religious knowledge at public schools, however, has not changed significantly. It still segregates children according to their individual religions to the present (C.-Y. Hoon, 2013). The government tried only to control the content of religious instruction, preventing controversial and sensitive statements from textbooks, without giving students opportunities to experience a multireligious context of learning. Students for that reason study all school subjects in a multireligious environment except for religious classes. They in these classes are divided based on their religious categories with no help to understand why it is so. In other words, since its inclusion as a compulsory subject in the early 1960s, the arrangement of religious instruction and education has not significantly changed. Many essays and books published advising how religious instruction should be handled in a multicultural and multireligious society, but none of those thoughts rigorously reflected in religious classes. The current state of religious instruction in Indonesia public schools seems to confirm Bekerman and Kopelowitz (2008) statement that the only communality these different religion followers have is "all want to transmit their traditions from one generation to another generation" (p.ix-x).

Likewise, religious instruction in Malaysia was designed from the beginning of its adoption in public school curriculum in a way that manifests the superiority of the Malay ethnic group to other ethnic groups. Islamic religious instruction is the only religious subject its provision in public schools is financed by the state, and is compulsory to the Muslim students. Students from other religious groups must take 
moral education classes from which Muslim students are exempted. Islamic religious instruction they receive is considered parallel to this moral education. Moreover, although the contemporary environment suggests that the country increasingly becomes diverse, and need to develop a multicultural setting for religious studies, the arrangement that gives favoritism to the Islamic religious education remains unchallenged to the present.

In Singapore, the inclusion of religious education in the state curriculum is unique. Religious subject is treated in a pragmatic and instrumentalistic way. It is just about a set of description of different religions to be known without any load of normativity. Therefore, when it was found that religious subject did not contribute effectively to the economic advancement of the country, the state used its coercive power to omit it from the state curriculum. In doing so, the government did not face a serious challenge from the civil society. If it was in Indonesia or Malaysia, this thing would not be easy to happen. A move to question the status quo of Islamic religious education in Malaysia or religious education in Indonesia definitely will face civil resistance.

In the three countries under study, religious education has to compete with moral education and citizenship education. In the last decade, there has been an assertion from educators and the public to emphasize values and moral education in the curriculum. Interestingly, the way each country arranged their values educations is different from one another. While Indonesia aligned moral education with religious education so that each religion taught inclusive of moral education, Malaysia provided moral education only for non-Muslim students, assuming that Muslim students learn the expected moral values through Islamic religious instruction (Balakrishnan, 2010; C. L. Hoon, 2010). On the other hand, Singapore omitted religious education from its state curriculum and replaced it with moral and citizenship education (Ho, 2013; Louis, 1998). After all, this arrangement is highly influenced by the historical relation between state, religion, and ethnicity in the three different countries.

Indonesia since its independence was divided based on religious categories, where Muslim groups tried to enshrine Islamic ideology in the constitution because they believed that Indonesia is the fruit of the Islamic struggle (jihad) against colonial occupations. Malaysia, on the other hand, from the beginning was defined by ethnic categories, where the Malay who happened to be majority Muslims was acknowledged as the right owner of the country. The constitution of the country explicitly proclaims the privilege that the Malay is entitled to. Singapore uniquely proclaimed itself as a secular state that strictly prevents religion to become the raison d'être for any state policies. Singapore, however, because its population is predominantly Chinese, is proud of its Confucius ethics that embraces learning and hard work, and respect for families and authorities. These values are always promoted by the state to energize their campaign of national survival and competitiveness.

In spite of this variation, the impact of the internationalization arena has penetrated into the state curriculum beyond the forces of the national agendas of development in each country. The three countries show an agreement on the importance of an integrative curriculum in which values education must play a strategic position to connect all school subjects at spiritual, social, knowledge, and skill level. Unlike Indonesia and Malaysia, Singapore clearly expresses in its new vision of education that the contemporary transnational economic world needs people who have knowledge and skills underpinned with moral values, such as respect, integrity, and concern with other 
fellow citizens. People with such character are capable to serve Singapore in the internationalization arena of economic development.

\section{Conclusions}

The recent wave of democratization and religious terror campaign has not significantly transformed the existing arrangement of religious education and instruction in Indonesia, Malaysia, and Singapore. The initial national agendas of development rooted in socio-political structure of the nation have resisted the effect of any efforts to reinvent the management of religious education. On the other hand, religious education, when it is defined as a valuable resource of moral values, has gained a new place within the national curriculum as a whole. It has become a medium for transmitting desirable moral values that should underpin all subjects taught at spiritual, social, knowledge and skill level. To sum up, the current state of religious education in the countries under study is a joint by-product of the national agenda of development and forces of internationalization arena.

\section{References}

Baidhawy, Z. (2007). Building Harmony and Peace through Multiculturalist Theology-Based Religious Education: An Alternative for Contemporary Indonesia. British Journal of Religious Education, 29(1), 15-30.

Balakrishnan, V. (2010). The Development of Moral Education in Malaysia. Asia Pacific Journal of Educatiors and Education, 25, 89-101.

Baratte, L. L. (2008). Religious Education and Peace Education: A Partnership Imperative for Our Day. In M. d. Souza, G. Durka, K. Engebretson, R. Jackson \& A. McGrady (Eds.), International Handbook of the Religious, Moral and Spiritual Dimensions in Education (pp. 243 -257). The Netherlands: Springer.

Bekerman, Z., \& Kopelowitz, E. (2008). Cultural Education - Cultural Sustainability: Towards an Honest Dialog With and Between Communities of Particular Practice Cultural Education-Cultural Sustainability: Minority, Diaspora, Indigenous and Ethno-Religious Groups in Multicultural Societies (pp. ix-x). New York: Routledge.

Brown, G. (2005). Making Ethnic Citizens: The Politics and Practice of Education in Malaysia. Queen Elizabeth House Department for International Development, University of Oxford. Centre for Researchon Inequality, Human Security and Ethnicity (CRISE). Oxford, UK.

Buckley, D. T., \& Mantilla, L. F. (2013). God and Governance: Development, State Capacity, and the Regulation of Religion. Journal for the Scientific Study of Religion, 52(2), 328-348.

Burhani, A. N. (2014). The Ahmadiyya and the Study of Comparative Religion in Indonesia: Controversies and Influences. Islam and Christian-Muslim Relations, 25(2), 141-158.

Carmody, B. (2010). Interreligious Education and the Question of Truth. In K. Engebretson, M. D. Souza, G. Durka \& L. Gearon (Eds.), International Handbook of Inter-religious Education (1) (pp. 41-55). New York: Springer.

Chaves, M. (1994). Secularization as Declining Religious Authority. Social Forces, 72(3), 749-774.

Choi, S. (2008). Korean Exceptionalism?: History, Culture, Politics, and Ethnic Relations in Northeast China. In Z. Bekerman \& E. Kopelowits (Eds.), 
Cultural Education-Cultural Sustainability: Minority, Diaspora, Indigenous and Ethno-Religious Groups in Multicultural Societies (pp. 147-163). New York: Routledge.

Cush, D. (2007). Should Religious Studies be Part of the Compulsory State School Curriculum? British Journal of Religious Education, 29(3), 217-227.

Depdiknas RI. (2007). Naskah Akademik Kajian Kebijakan Kurikulum Mata Pelajaran Pendidikan Agama. Depdiknas RI. Jakarta.

EPU. (2013). The Malaysian Economy in Figures 2013 (Updated Edition). Retrieved April 15, 2015, from http://www.epu.gov.my/documents/10124/1e9cd2e5-67a8-4b6c-b530b1448a6a1475

Estivalezes, M. (2008). Teaching about Religion at School in France. In M. d. Souza, G. Durka, K. Engebretson, R. Jackson \& A. McGrady (Eds.), International Handbook of the Religious, Moral and Spiritual Dimensions in Education (pp. 475-486). The Netherlands: Springer.

Feinberg, W. (2006). Religious Schools and Education for Democratic Citizenry for Goodness Sake. New York: Routledge.

Filus, D. (2008). Religious Education in Contemporary Japan. In M. d. Souza, G. Durka, K. Engebretson, R. Jackson \& A. McGrady (Eds.), International Handbook of the Religious, Moral and Spiritual Dimensions in Education (pp. 1039-1053). The Netherlands: Springer.

Gopinathan, S. (1980). Moral Education in a Plural Society: A Singapore Case Study. International Review of Education, 26(2), 171-185.

Grelle, B. (2008). Defining and Promoting the Study of Religion in British and American Schools. In M. d. Souza, G. Durka, K. Engebretson, R. Jackson \& A. McGrady (Eds.), International Handbook of the Religious, Moral and Spiritual Dimensions in Education (pp. 461-474). The Netherlands: Springer.

Hashim, C. N., \& Langgulung, H. (2006). Islamic Religious Curriculum in Muslim Countries: The Experiences of Indonesia and Malaysia. Bulletin of Education \& Research, 30(1), 1-19.

Hefner, R. W. (2001). Multiculturalism and Citizenship in Malaysia, Singapore, and Indonesia. In R. W. Hefner (Ed.), The Politics of Multiculturalism: Pluralism and Citizenship in Malaysia, Singapore, and Indonesia (pp. 1-59). Honolulu: University of Hawai'i Press.

Ho, L.-C. (2013). National and Global Citizenship Education: Case Studies from Two Singapore Social Studies Classrooms. In Z. Deng, S. Gopinathan \& C. K. Lee (Eds.), Globalization and the Singapore Curriculum: From Policy to Classroom (pp. 169-185). Singapore: Springer.

Hoon, C.-Y. (2013). Multicultural Citizenship Education in Indonesia: The Case of a Chinese Christian School. Journal of Southeast Asian Studies, 44(3), $490-510$.

Hoon, C. L. (2010). An Appraisal on the Implementation of Moral Education for Schools in Malaysia. Paper presented at the 4th International Conference on Teacher Education; a Joint Conference - UPI \& UPSI Bandung, Indonesia, 810 November 2010, Bandung.

Hunges, P. (2008). The Future of Religious Education in the Context of Postmodernity. In M. d. Souza, G. Durka, K. Engebretson, R. Jackson \& A. 
McGrady (Eds.), International Handbook of the Religious, Moral and Spiritual Dimensions in Education (pp. 349-362). The Netherlands: Springer.

Kadir, S. (2010). Uniquely Singapore: The Management of Islam in a Small Island Republic. Islam and Civilization Renewal, 2(1), 156-176.

Kelabora, L. (1976). Religious Instruction Policy in Indonesia. Asian Survei, 16(3), 230-248.

Kelabora, L. (1979). Assumptions Underlying Religious Instruction in Indonesia. Comparative Education, 15(3), 325-339.

Kemendikbud RI. (2014). Paparan Menteri Pendidikan dan Kebudayaan: Press Workshop Implementasi Kurikulum 13. Jakarta: Kemendikbud RI.

Khairiyah, N., \& Zen, E. S. (2014). Buku Guru Pendidikan Agama Islam dan Budi Pekerti untuk Kelas X. Jakarta: Kemendikbud RI.

Kollar, N. R. (2009). Defending Religious Diversity in Public Schools: A Practical Guide for Building Our Democracy and Deepening Our Education. Santa Barbara, CA: Praeger.

Kompas Online. (2013). Cegah Tawuran Tak Bisa dengan Pengajaran Moral Saja. Retrieved April 1, 2014, from http://megapolitan.kompas.com/read/2013/10/11/2306127/Cegah.Tawuran.Tak .Bisa.dengan.Pengajaran.Moral.Saja

Lee, W. O. (2013). The Development of a Future-Oriented Citizenship Curriculum in Singapore: Convergence of Character and Citizenship Education and Curriculum 2015. In Z. Deng, S. Gopinathan \& C. K. Lee (Eds.), Globalization and the Singapore Curriculum: From Policy to Classroom (pp. 241-260). Singapore: Springer.

Louis, E. T. (1998). Religious Harmony in Singapore. (PhD), Massey University, Palmerston North, NZ.

Mahmood, J. (2014). Civics and Citizenship Education in Malaysia: The Voice of Micro Policy Enactors. (PhD), Cardiff University, Wales, UK.

Malaysia Today. (2014). Rise of Religious Classes in Public Schools Questioned. Retrieved March 6, 2015, from http://www.malaysia-today.net/rise-ofreligious-classes-in-public-scho...

McRae, D. (2013). A Few Poorly Organized Men: Interreligious Violence in Poso, Indonesia. Leiden: Brill.

Miranda, E. O. y. (2010). Religious Pluralism and the Paradigm International Handbook of Inter-religious Education (1) (pp. 5-24). New York: Springer.

Moran, G. (2008). Religious Education and the Nation-State. In M. d. Souza, G. Durka, K. Engebretson, R. Jackson \& A. McGrady (Eds.), International Handbook of the Religious, Moral and Spiritual Dimensions in Education (2 ed., pp. 41-50). The Netherlands: Springer.

Nor, M. R. M., \& Othman, W. M. T. W. (2011). Sejarah dan Perkembangan Pendidikan Islam di Malaysia. Jurnal At-Ta'dib, 6(1), 59-78.

Nurjanah, A. (2015). Seks Bebas di Kalangan Pelajar Memprihatinkan. Retrieved January 30, 2015, from http://daerah.sindonews.com/read/957516/21/seksbebas-di-kalangan-pelajar-memprihatinkan-1422523835

Saeed, A. (1999). Towards Religious Tolerance through Reform in Islamic Education: The Case of the State Institute of Islamic Studies of Indonesia. Indonesia and the Malay World, 27(79), 177-191. 
Schreiner, P. (2002). Religious Education in the European Context. In L. Broadbent \& A. Brown (Eds.), Issues in Religious Education (pp. 82-93). New York: RoutledgeFalmer.

Singapore's Department of Statistics. (2014). Population in Brief 2014. Retrieved March 4, 2015, from http://www.nptd.gov.sg/portals/0/homepage/highlights/population-in-brief2014.pdf

Skeie, G. (2008). Plurality and Pluralism in Religious Education. In M. d. Souza, G. Durka, K. Engebretson, R. Jackson \& A. McGrady (Eds.), International Handbook of the Religious, Moral and Spiritual Dimensions in Education (pp. 307-319). The Netherlands: Springer.

Tan, C. (2008). Creating 'Good Citizens' and Maintaining Religious Harmony in Singapore. British Journal of Religious Education, 30(2), 133-142.

Tan, C. (2012). Deep Culture Matters: Multiculturalism in Singapore Schools. International Journal of Educational Reform, 21(1), 24-38.

Tempo. (2012). Bagaimana Kronologi Syiah Masuk Sampang? Retrieved September 20, 2014, from http://nasional.tempo.co/read/news/2012/09/02/173426989/bagaimanakronologi-syiah-masuk-sampang

van Klinken, G. (2007). Communal Violence and Democratization in Indonesia: Small Town Wars. London: Routledge.

Welch, A. (2006). Blurred Vision?: Public and Private Higher Education in Indonesia. Higher Education, 54(5), 665-687.

Williams, K. (2008). Religion and Educational Policy in France. In M. d. Souza, G. Durka, K. Engebretson, R. Jackson \& A. McGrady (Eds.), International Handbook of the Religious, Moral and Spiritual Dimensions in Education (pp. 1031-1038). The Netherlands: Springer.

Yeoh, C. R. (2006). Malaysia, Truly Asia? Religious Pluralism in Malaysia. Retrieved Mei 3, 2015, from http://pluralism.org/research/reports/yeoh/Pluralism Malaysia.doc

Zyngier, D. (2013). Religious Instruction Has No Place in Our Public Schools. Retrieved August 7, 2014, from http://monash.edu/news/show/religiousinstruction-has-no-place-in-our...[] 